\title{
Clinical and pathological factors affecting lymph node metastasis in patients operated on with the diagnosis of colorectal cancer
}

\section{Kolerektal kanser tanısıyla ameliyat olmuş hastalardaki lenf nodu metastazına etki eden klinik ve patolojik faktörler}

\author{
Mehmet Akif ÜSTÜNER ${ }^{1}$, Enver ILHAN², Eyüp YELDAN ${ }^{2}$, Asuman ARGON ${ }^{3}$, Enver VARDAR ${ }^{3}$ \\ ${ }^{1}$ Dr. Abdurrahman Yurtaslan Ankara Onkolojı Eğitim ve Araştırma Hastanesi, Ankara \\ ${ }^{2}$ İzmir Bozyaka Ĕ̈itim ve Araştırma Hastanesi Genel Cerrahi Kliniği, İzmir \\ ${ }^{3}$ İzmir Bozyaka Ĕ̆itim ve Araştırma Hastanesi Patoloji Kliniği İzmir
}

\begin{abstract}
Objective: We aimed to examine the clinical and the pathological factors that affect lymph node metastasis, which is an important prognostic factor in the survival of the patients with colorectal cancer, and to determine the most appropriate patient-centered treatment method.

Methods: The file records and electronic data of the patients who had been operated on with the diagnosis of colorectal cancer at the General Surgery Clinic between May 2008 and December 2012 were retrospectively evaluated.

Results: Seventy-four patients including 50 males $(67.6 \%)$ and 24 females $(32.4 \%)$ were included in the study. The mean age of the patients was 69.3 years (range: $38-60$ years). While lymphovascular invasion was observed in 21 (28.4\%), and perineural invasion in 19 $(25.7 \%)$ patients. When the growth pattern was examined, 48 patients $(64.9 \%)$ demonstrated ulcerovegetative, 18 patients $(24.3 \%)$ ulcerated, eight patients $(10.8 \%)$ polyp-type growth patterns. The most frequent tumor localization was the middle third of rectum $(n=20 ; 27 \%)$ and the most common type of surgery was the Miles operation $(n=16$; $21.6 \%$ ).

Conclusion: In conclusion, the risk of LNM significantly increases in patients with colorectal cancer who have surgical radial margin, lymphovascular and perineural invasion. Over time, the other risk factors affecting LNM will be determined with large scale studies that can be conducted together with advancing technology and broad sources of knowledge. In this way, minimally invasive surgery can be performed on cases with colon cancer and the patients will be protected from the side effects of unnecessary chemotherapy.
\end{abstract}

Key words: Lymph node metastasis, colorectal cancer, lypmphovasculer invasion

\section{$\ddot{\mathbf{O Z Z}}$}

Amaç: Kolorektal kanserli hastalarda sağkalımda önemli bir prognostik faktör olan lenf nodu metastazına etki eden klinik ve patolojik faktörleri inceleyerek hasta merkezli en uygun tedaviyi belirlemeyi amaçladık.

Yöntemler: Cerrahi kliniğinde Mayıs 2008-Aralık 2012 tarihleri arasında kolerektal kanser tanısıla ameliyat edilen hastaların dosya kayıtları ve elektronik ortam bilgileri retrospektif olarak incelendi.

Bulgular: Araştırmamızda bulunan 74 hastanın 50'si $(\% 67,6)$ erkek, 24'ü $(\% 32,4)$ kadınd. Hastalarımızın yaş ortalaması $69,3(38-60)$ yıl olarak bulundu, $50(\% 67,6)$ hasta 65 yaş üstünde, $24(\% 32,4)$ hasta 65 ve altındaydı. Yirmi bir $(\% 28,4)$ hastada lenfovasküler invazyon gözlenirken $19(\% 25,7)$, hastada perinöral invazyon gözlendi. Gelişim paternine baktığımızda $48(\% 64,9)$ hasta ülserovegatatif, $18(\% 24,3)$ hasta ülsere, $8(\% 10,8)$ hastanın polip tipte gelişim paterni gösteriyordu. En sık gözlenen tümör lokalizasyonu rektum orta $1 / 3$ olarak bulurken $(20(\% 27))$, en sık yapılan operasyon Miles operasyonu olarak karşımıza çıktı $(16(\% 21,6))$.

Sonuç: Sonuç olarak, kolon kanserlerinde lenfovasküler invazyon, perinöral invazyona sahip hastalarda LNM riski önemli ölçüde artmaktadır. Zaman içinde, gelişen teknoloji ve bilgi birikimiyle yapılacak olan daha kapsamlı çalışmalarla LNM'yi etkileyen diğer risk faktörler de bulunacaktır. Bu sayede kolon kanserlerinde minimal invaziv cerrahi uygulanabilecek ve hastalar gereksiz kemoterapinin yan etkilerinden korunacaktır.

Anahtar kelimeler: Lenf nodu metastazı, kolorektal kanser, lenfovasküler invazyon
Alındığı tarih: 19.08 .2015

Kabul tarihi: 27.08 .2015

Yazışma adresi: Uzm. Dr. Mehmet Akif Üstüner, Milenyum Sitesi Yaşamkent Mahallesi, Çankaya0600-Ankara

e-mail: dr_ustuner@hotmail.com 


\section{INTRODUCTION}

Lymph node metastasis in colon cancers is one of the prognostic factors that determine the necessity of adjuvant chemotherapy. As death in colon cancers is generally related to metastatic invasion, it is necessary to remove the lymph nodes in addition to the resection of the primary tumor. Knowing the factors increasing the lymph node metastasis is important for the approach. If the presence of lymph node invasion can be predicted during the preoperative period, the most appropriate treatment option for the patient will be planned. By predetermining the risk factors that can affect lymph node metastasis, the patients who will benefit from partial resection or endoscopic resection can be identified ${ }^{(1)}$. In other words, since there is no LNM, the patients that can not benefit from chemotherapy can be determined ${ }^{(1)}$. The present study aimed to examine the clinical and the pathological factors that affect lymph node metastasis, which is an important prognostic factor in survival of the patients with colorectal cancer and to determine the most appropriate patient-centered treatment method.

\section{MATERIAL and METHOD}

The file records and electronic data of the patients who had been operated on with the diagnosis of colorectal cancer in the General Surgery Clinic between May 2008 and December 2012 were retrospectively evaluated. Statistical Package for the Social Sciences (SPSS) 21 program was used for data analysis. Kolmogorov-Smirnov test, Shapiro-Wilk test, independent-Samples T-test, Mann-Whitney U-test, Pearson's correlation, Spearman's rho tests, Pearson's chi-square test were used.

Patients who underwent surgery for colorectal cancer without any other primary cancer were included in the study

Patients with recurrent colorectal cancer, stage 4 cancer and cases with another primary cancer were not included in the study.

\section{RESULTS}

Seventy-four patients, 50 males $(67.6 \%)$ and 24 females $(32.4 \%)$, were included in the study. The mean age of the patients was 69.3 (38-60) years. In 65 patients $(87.8 \%)>12$, and in 9 patients $(12.2 \%)$ less than 12 lymph nodes were removed. While the lymph node metastasis was positive in 39 (52.7\%) and negative in 35 patients $(47.3 \%)$. Sixty-one $(82.4 \%)$ patients were operated on under elective conditions, and 13 patients (17.6\%) under emergency conditions. Tumors developed from polyps in four patients $(5.4 \%)$. Synchronous tumors were observed in four $(5.4 \%)$. patients Synchronous polyps were observed in $16(21.6 \%)$ patients. Average size of the tumors was $5 \mathrm{~cm}(1.5-11)$, the tumor size was $\leq 4 \mathrm{~cm}$ in $3141.9 \%$ ) and $\geq 4 \mathrm{~cm}$ in 43 patients $(58.1 \%)$. A mucinous component was seen in the pathological examination of 14 patients (18.9\%). Lymphovascular invasion was observed in 21 patients $(28.4 \%)$ and perineural invasion in 19 patients $(25.7 \%)$. Surgical margin positivity was found in pathological examination of the specimens of nine patients (12.2\%).

Forty-eight patients (64.9\%) demonstrated ulcerovegetative, 18 patients $(24.3 \%)$ ulcerated, and eight patients (10.8\%) polyp-type growth patterns. Histological grading were reported as Grade 1 in six (8.1\%), Grade 2 in $60(81.1 \%)$, and Grade 3 in eight patients (10.8\%). TNM classification of the patients was reported as $\mathrm{T} 1 \mathrm{in}$, three $(4.1 \%), \mathrm{T} 2$, in seven (9.5\%), T3 in $44(59.5 \%)$, and $\mathrm{T} 4$ in $20(27 \%)$ patients were $\mathrm{T} 4$. While lymph node metastasis was not observed in 34 patients (45.9\%) (N0), while 22 patients $(29.7 \%)$ were $\mathrm{N} 1$ and 18 patients $(24.3 \%)$ were N2. In the clinical staging, seven patients (9.5\%) were Stage 1, 26 patients (35.1\%) Stage 2, and 41 patients $(55.4 \%)$ Stage 3 . The most frequent tumor localization was the middle third of the rectum $(n=20 ; 27 \%)$ and the most common type of surgery was the Miles operation ( $n=16 ; 21.6 \%)$.

When the factors affecting the lymph node metastasis were examined, a significant correlation was found between lymph node metastasis and perineural 
invasion $(\mathrm{p}<0.001)$, lymphovascular invasion $(\mathrm{p}<0.001)$, and positive surgical radial margin (p:0.03), (Table 1).

In patients with positive lymph node metastasis, the most common growth pattern was ulcerovegetative type ( $\mathrm{n}=21 ; 60 \%)$, the most common histological grade was Grade $2(n=29 ; 82.9 \%)$, the most common stage was Stage T3 $(n=19 ; 54.3 \%)$, while the most frequently involved tumor segment was the middle third of the rectum $(n=7 ; 20 \%)$ and cecum $(n=7$; $20 \%$ ). Besides, the most frequently performed operation was right hemicolectomy $(n=7 ; 20 \%)$. All of these results were not statistically significant.

Common characteristics of the patients in which insufficient lymph node was removed were as follows :being over 65 years of age $(n=6 ; 66.7 \%)$; male gender $(n=7 ; 77.8 \%)$; colonic location $(n=3 ; 33.3 \%)$; Stage $3(n=5 ; 55.6 \%)$; NO $(n=4 ; 44.4 \%)$; Grade 2

Table 1. Factors affecting lymph node metastasis.

\begin{tabular}{|c|c|c|c|c|c|}
\hline & & \multicolumn{2}{|c|}{ Metastasis } & \multirow[b]{2}{*}{ P value } & \multirow[b]{2}{*}{ Eta coefficient } \\
\hline & & $\begin{array}{l}\text { Absent } \\
\text { N (\%) }\end{array}$ & $\begin{array}{c}\text { Present } \\
\text { N (\%) }\end{array}$ & & \\
\hline \multirow[t]{2}{*}{ Age } & $\leq 65 / 65<$ & $12(34.3 \%) / 23(65.7 \%)$ & $12(30.8 \%) / 27(69.2 \%)$ & 0.807 & \\
\hline & Mean \pm SD. & $68.6 \pm 11.4$ & $69.8 \pm 12.6$ & 0.659 & \\
\hline \multirow[t]{2}{*}{ Gender } & Female/Male & $9(25.7 \%) / 26(74.3 \%)$ & $15(38.5 \%) / 24(61.5 \%)$ & 0.321 & \\
\hline & $\leq 12 / 12<$ & $4(11.4 \%) / 31(88.6 \%)$ & $5(12.8 \%) / 34(87.2 \%)$ & 1 & \\
\hline Number of Lymph Nodes & Median $\pm I Q R$ & $25 \pm 16$ & $22 \pm 18$ & 0.454 & \\
\hline Emergent-Elective Surgery & Emergent/Elective & $6(17.1 \%) / 29(82.9 \%)$ & $7(17.9 \%) / 32(82.1 \%)$ & 1 & \\
\hline The Basis of Polyp & Absent / Present & $32(91.4 \%) / 3(8.6 \%)$ & $38(97.4 \%) / 1(2.6 \%)$ & 0.339 & \\
\hline Synchronous TM & Absent / Present & $34(97.1 \%) / 1(2.9 \%)$ & $36(92.3 \%) / 3(7.7 \%)$ & 0.617 & \\
\hline Synchronous Polyp & Absent / Present & $27(77.1 \%) / 8(22.9 \%)$ & $31(79.5 \%) / 8(20.5 \%)$ & 1 & \\
\hline \multirow[t]{2}{*}{ The Largest Size } & $\leq 4 / 4<$ & $18(51.4 \%) / 17(48.6 \%)$ & $13(33.3 \%) / 26(66.7 \%)$ & 0.158 & \\
\hline & Mean \pm SD & $4.6 \pm 2$ & $5.3 \pm 1.9$ & 0.145 & \\
\hline Mucinous Component & Absent / Present & $29(82.9 \%) / 6(17.1 \%)$ & $31(79.5 \%) / 8(20.5 \%)$ & 0.773 & \\
\hline LVI & Absent / Present & $34(97.1 \%) / 1(2.9 \%)$ & $19(48.7 \%) / 20(51.3 \%)$ & $<0.001$ & 0.536 \\
\hline PNI & Absent / Present & $34(97.1 \%) / 1(2.9 \%)$ & $21(53.8 \%) / 18(46.2 \%)$ & $<0.001$ & 0.495 \\
\hline \multirow[t]{2}{*}{ CS } & Absent / Present & $34(97.1 \%) / 1(2.9 \%)$ & $31(79.5 \%) / 8(20.5 \%)$ & 0.03 & 0.270 \\
\hline & Polyposis & $6(17.1 \%)$ & $2(5.1 \%)$ & & \\
\hline \multirow[t]{3}{*}{ Growth Pattern } & Ulcerated & $8(22.9 \%)$ & $10(25.6 \%)$ & 0.274 & \\
\hline & Ulcerovegetative & $21(60 \%)$ & $27(69.2 \%)$ & & \\
\hline & Grade I & $5(14.3 \%)$ & $1(2.6 \%)$ & & \\
\hline \multirow[t]{3}{*}{ Histological Grade } & Grade II & $29(82.9 \%)$ & $31(79.5 \%)$ & 0.032 & \\
\hline & Grade III & $1(2.9 \%)$ & $7(17.9 \%)$ & & \\
\hline & $\mathrm{T} 1$ & $2(5.7 \%)$ & $1(2.6 \%)$ & & \\
\hline \multirow[t]{4}{*}{$\mathrm{T}$} & $\mathrm{T} 2$ & $5(14.3 \%)$ & $2(5.1 \%)$ & 0.520 & \\
\hline & $\mathrm{T} 3$ & $19(54.3 \%)$ & $25(64.1 \%)$ & & \\
\hline & $\mathrm{T} 4$ & $9(25.7 \%)$ & $11(28.2 \%)$ & & \\
\hline & Right Hemicolectomy & $11(31.4 \%)$ & $4(10.3 \%)$ & - & \\
\hline \multirow[t]{14}{*}{ Type of Surgery } & Left Hemicolectomy & $8(22.9 \%)$ & $7(17.9 \%)$ & & \\
\hline & Subtotal Colectomy & $1(2.9 \%)$ & $0(0 \%)$ & & \\
\hline & Total Colectomy & $1(2.9 \%)$ & $1(2.6 \%)$ & & \\
\hline & Anterior Resection & $1(2.9 \%)$ & $3(7.7 \%)$ & & \\
\hline & Low-Anterior Resection & $4(11.4 \%)$ & $7(17.9 \%)$ & & \\
\hline & Very Low Anterior Resection & $0(0 \%)$ & $0(0 \%)$ & & \\
\hline & Miles & $7(20 \%)$ & $9(23.1 \%)$ & & \\
\hline & Sigmoid Colon Resection & $1(2.9 \%)$ & $7(17.9 \%)$ & & \\
\hline & Transverse Colon Resection & $1(2.9 \%)$ & $1(2.6 \%)$ & & \\
\hline & Cecum & $7(20 \%)$ & $2(5.1 \%)$ & & \\
\hline & Ascending colon & $3(8.6 \%)$ & $2(5.1 \%)$ & & \\
\hline & Hepatic Flexura & $3(8.6 \%)$ & $1(2.6 \%)$ & & \\
\hline & Transverse Colon & $3(8.6 \%)$ & $0(0 \%)$ & & \\
\hline & Splenic Flexura & $3(8.6 \%)$ & $4(10.3 \%)$ & & \\
\hline \multirow[t]{6}{*}{ Tumor Localization } & Descending Colon & $2(5.7 \%)$ & $2(5.1 \%)$ & - & \\
\hline & Sigmoid Colon & $4(11.4 \%)$ & $11(28.2 \%)$ & & \\
\hline & Rectosigmoid Junction & $1(2.9 \%)$ & $1(2.6 \%)$ & & \\
\hline & Rectum Upper 1/3 & $0(0 \%)$ & $2(5.1 \%)$ & & \\
\hline & Rectum Middle 1/3' ü & $7(20 \%)$ & $13(33.3 \%)$ & & \\
\hline & Rectum Lower 1/3' ü & $2(5.7 \%)$ & $1(2.6 \%)$ & & \\
\hline
\end{tabular}

Pearson Chi-Square Test (Monte Carlo), Independent T-Test - Mann-Whitney U-Test (Monte Carlo), SD. Standard deviation - IQR: Interquartile Range 
$(\mathrm{n}=8 ; 88.9 \%)$; ulcerovegetative type $(\mathrm{n}=6 ; 66.7 \%)$; tumor size smaller than $4 \mathrm{~cm}(\mathrm{n}=5 ; 55.6 \%)$; and elective operation $(n=6 ; 66.7 \%)$, (Table 2). However, these data were not statistically significant.

When the emergent and elective operations were compared: The aged population in patients operated on under emergent conditions were higher than the patients operated on under elective conditions (p:0.049). The number of synchronous polyps in patients operated on under elective conditions was greater than the patients operated on under emergent conditions (p:0.028).

Table 2. Comparison of the patients with sufficient lymph node removal $(12<)$ with the patients with insufficient lymph node removal $((\leq 12)$.

\begin{tabular}{|c|c|c|c|c|}
\hline & & Number o & ymph nodes & \\
\hline & & $\begin{array}{c}\leq 12 \\
\mathrm{~N}(\%)\end{array}$ & $\begin{array}{c}12< \\
\mathbf{N}(\%)\end{array}$ & P value \\
\hline Age & $\leq 65 / 65<$ & $3(33.3 \%) / 6(66.7 \%)$ & $21(32.3 \%) / 44(67.7 \%)$ & 1 \\
\hline & Mean \pm SD. & $69.6 \pm 9.3$ & $69.2 \pm 12.4$ & 0.937 \\
\hline Gender & Female / Male & $2(22.2 \%) / 7(77.8 \%)$ & $22(33.8 \%) / 43(66.2 \%)$ & 0.709 \\
\hline Emergent-elective surgeries & Emergent / Elective & $3(33.3 \%) / 6(66.7 \%)$ & $10(15.4 \%) / 55(84.6 \%)$ & 0.346 \\
\hline Number of metastasis & Median $\pm \mathrm{IQR}$ & $2 \pm 4$ & $3 \pm 5$ & 0.559 \\
\hline The basis of polyp & Absent / Present & $8(88.9 \%) / 1(11.1 \%)$ & $62(95.4 \%) / 3(4.6 \%)$ & 0.412 \\
\hline Synchronous TM & Absent / Present & $9(100 \%) / 0(0 \%)$ & $61(93.8 \%) / 4(6.2 \%)$ & 1 \\
\hline Synchronous Polyp & Absent / Present & $7(77.8 \%) / 2(22.2 \%)$ & $51(78.5 \%) / 14(21.5 \%)$ & 1 \\
\hline The largest size & $\leq 4 / 4<$ & $5(55.6 \%) / 4(44.4 \%)$ & $26(40 \%) / 39(60 \%)$ & 0.478 \\
\hline & Mean \pm SD & $5.1 \pm 2.6$ & $5 \pm 1.9$ & 0.891 \\
\hline Mucinous component & Absent / Present & $6(66.7 \%) / 3(33.3 \%)$ & $54(83.1 \%) / 11(16.9 \%)$ & 0.358 \\
\hline LVI & Absent / Present & $4(44.4 \%) / 5(55.6 \%)$ & $49(75.4 \%) / 16(24.6 \%)$ & 0.107 \\
\hline PNI & Absent / Present & $7(77.8 \%) / 2(22.2 \%)$ & $48(73.8 \%) / 17(26.2 \%)$ & 1 \\
\hline CS & Absent / Present & $8(88.9 \%) / 1(11.1 \%)$ & $57(87.7 \%) / 8(12.3 \%)$ & 1 \\
\hline & Polypoid & $1(11.1 \%)$ & $7(10.8 \%)$ & \\
\hline Growth pattern & Ulcerated & $2(22.2 \%)$ & $16(24.6 \%)$ & 1 \\
\hline & Ulcerovegetative & $6(66.7 \%)$ & $42(64.6 \%)$ & \\
\hline & Grade I & $1(11.1 \%)$ & $5(7.7 \%)$ & \\
\hline Histological Grade & Grade II & $8(88.9 \%)$ & $52(80 \%)$ & 0.638 \\
\hline & Grade III & $0(0 \%)$ & $8(12.3 \%)$ & \\
\hline & $\mathrm{T} 1$ & $1(11.1 \%)$ & $2(3.1 \%)$ & \\
\hline & $\mathrm{T} 2$ & $2(22.2 \%)$ & $5(7.7 \%)$ & 0.110 \\
\hline $\mathrm{T}$ & $\mathrm{T} 3$ & $6(66.7 \%)$ & $38(58.5 \%)$ & \\
\hline & $\mathrm{T} 4$ & $0(0 \%)$ & $20(30.8 \%)$ & \\
\hline & No & $4(44.4 \%)$ & $30(46.2 \%)$ & \\
\hline $\mathrm{N}$ & N1 & $3(33.3 \%)$ & $19(29.2 \%)$ & 1 \\
\hline & $\mathrm{N} 2$ & $2(22.2 \%)$ & $16(24.6 \%)$ & \\
\hline & Stage I & $2(22.2 \%)$ & $5(7.7 \%)$ & \\
\hline Clinical Stage & Stage II & $2(22.2 \%)$ & $24(36.9 \%)$ & 0.383 \\
\hline & Stage III & $5(55.6 \%)$ & $36(55.4 \%)$ & \\
\hline & Right Hemicolectomy & $1(11.1 \%)$ & $14(21.5 \%)$ & \\
\hline Type of surgery & Left Hemicolectomy & $2(22.2 \%)$ & $13(20 \%)$ & - \\
\hline & Subtotal Colectomy & $0(0 \%)$ & $1(1.5 \%)$ & \\
\hline & Total Colectomy & $0(0 \%)$ & $2(3.1 \%)$ & \\
\hline & Anterior Resection & $0(0 \%)$ & $4(6.2 \%)$ & \\
\hline & Low Anterior Resection & $1(11.1 \%)$ & $10(15.4 \%)$ & \\
\hline & Miles & $2(22.2 \%)$ & $14(21.5 \%)$ & \\
\hline & Sigmoid Colon Resection & $2(22.2 \%)$ & $6(9.2 \%)$ & \\
\hline & Transverse Colon Resection & $1(11.1 \%)$ & $1(1.5 \%)$ & \\
\hline & Cecum & $1(11.1 \%)$ & $8(12.3 \%)$ & \\
\hline & Ascending colon & $0(0 \%)$ & $5(7.7 \%)$ & \\
\hline & Hepatic Flexura & $0(0 \%)$ & $4(6.2 \%)$ & \\
\hline & Transverse Colon & $0(0 \%)$ & $3(4.6 \%)$ & \\
\hline & Splenic Flexura & $0(0 \%)$ & $7(10.8 \%)$ & \\
\hline Tumor localization & Descending colon & $3(33.3 \%)$ & $1(1.5 \%)$ & - \\
\hline & Sigmoid Colon & $1(11.1 \%)$ & $14(21.5 \%)$ & \\
\hline & Rectosigmoid junction & $1(11.1 \%)$ & $1(1.5 \%)$ & \\
\hline & Rectum upper $1 / 3$ & $0(0 \%)$ & $2(3.1 \%)$ & \\
\hline & Rectum middle $1 / 3$ 'ü & $2(22.2 \%)$ & $18(27.7 \%)$ & \\
\hline & Rectum lower 1/3’ü & $1(11.1 \%)$ & $2(3.1 \%)$ & \\
\hline
\end{tabular}

Pearson Chi-Square Test (Monte Carlo), Independent T-Test - Mann-Whitney U-Test (Monte Carlo), SD; Standard deviation - IQR: Interquartile Range 


\section{DISCUSSION}

Prognostic factors are useful for all cancer treatments. In colorectal surgery, there are various clinical and pathological prognostic factors as human leukocyte antigen (HLA1), depth, histological type, lymphovascular invasion, budding, number of lymph nodes analyzed after surgery $(<12)$ as recommended by ESMO guidelines or NCCN Guidelines Version 2 $(2014)^{(2,3)}$. The HLA class I expression is prognostic factor in colorectal cancer patients with stage II disease ${ }^{(3)}$. Lymph node involvement is certainly the most important prognostic factor in colon cancer of all stages.

The curative treatment option in colorectal cancers is the removal of all mesenteric lymph nodes in which the tumor drains, within clean upper and lower surgical margins. While some investigators support the therapeutic benefits of complete lymph node excision, others believe that it provides the possibility of more accurate staging ${ }^{(4)}$. The most important factor that should be paid attention to during adjuvant chemotherapy is lymph node involvement ${ }^{(5)}$. In addition, preoperative lymph node involvement has great importance in the planning of neoadjuvant therapy in rectal cancers. While inadequate staging leads to lower survival rates, higher staging causes the patient to receive unnecessarily high dose chemotherapy ${ }^{(6)}$. Chemotherapeutic agents cause Grade 3-4 neutropenia and peripheral neuropathy at a rate of $40 \%{ }^{(7,8)}$. However the number of removed lymph nodes, and metastatic lymph nodes are affected by the type of surgery, being either emergent or elective, by the surgical technique, and by the experience of the pathologist. The minimum number of lymph nodes that should be removed is still controversial ${ }^{(9)}$. Many organizations, mainly the American Society of Clinical Oncology (ASCO), the American Joint Committee on Cancer (AJCC), and the National Cancer Institute (NCI), have reported that at least 12 lymph nodes should be dissected as ${ }^{(6,10,11)}$. Therefore, we determined the minimum number of lymph nodes that should be removed. We analyzed the patients from whom less than 12 lymph nodes were removed. Contrary to what is believed, removal of insufficient number of lymph nodes was not found to be statistically significant especially male patients aged above 65 years, with ulcerovegetative type Stage 3, N0, Grade 2 smaller $(<4 \mathrm{~cm})$ tumors localized in the descending colon. When the emergent and elective surgeries were compared, the aged population in patients operated under emergency conditions were higher than the elective operations (p:0.049). The number of synchronous polyps in patients operated on under elective conditions was higher than those found in patients who underwent emergent operations (p:0.028).

In the previous studies, the factors increasing the risk of lymph node metastasis (LNM) were reported as age, poor differentiation, lymphovascular invasion, close surgical margin, smooth or depressed lesions, the depth of tumor invasion, and progression of the tumor towards the area that it invades by budding ${ }^{(12,13)}$. In the current study, when the factors affecting the lymph node metastasis were examined, it was observed that perineural invasion $(p<0.001)$, lymphovascular invasion $(\mathrm{p}<0.001)$, positive surgical margin (p:0.03) significantly increased the lymph node metastasis.

In patients with positive lymph nodes, the most common growth pattern was ulcerovegetative type $(\mathrm{n}=21 ; 60 \%)$, the histological grade was at most Grade 2 ( $\mathrm{n}=29 ; 82.9 \%)$, and the most frequently involved tumor segment was the middle third of the rectum $(n=7 ; 20 \%)$, and cecum $(n=7 ; 20 \%)$, while most frequently right hemicolectomy was performed $(\mathrm{n}=7 ; 20 \%)$.

The presence of LNM decreases the survival times at a rate of $30 \%$. Together with the developing technology day by day, LNM is treated by local excision or endoscopic excision. Much the same as the polyp-based tumors that have submucosal invasion, rectum cancers are treated by less invasive methods such as transanal resection. If the pathological result of the patient after endoscopic procedure or transanal resection is reported as submucosal invasion, it is 
necessary to operate on the patient for the second time to complete the treatment. However, when the presence of LNM in only $10 \%$ of these tumors is considered, $90 \%$ of the patients are unnecessarily operated on for the second time ${ }^{(1,14)}$. In studies investigating the factors affecting LNM in colorectal cancers, it has been observed that the most important risk factor is lymphovascular invasion ${ }^{(12,14,15)}$. In the current study, while the most important risk factor was perineural invasion, lymphovascular invasion was the second most important risk factor.

In a multivariate analysis that was performed on 3,759 patients, Voyer et al. ${ }^{(16)}$ found that tumors were most frequently localized in the sigmoid colon, the rate of lymph node positivity was most commonly seen in T3 tumors, and in patients in which right hemicolectomy was done. In the current study, similar to the study of Voyer et al. ${ }^{(16)}$, lymph node positivity was most frequently observed in patients at Stage T3 $(n=19 ; 54.3 \%)$ and the most commonly performed operation was right hemicolectomy $(n=7$; $20 \%$ ); however, this was not a statistically significant finding.

In the study that was performed by Nascimbeni et al. ${ }^{(13)}$, they demonstrated that Grade 3 and Grade 4 poorly differentiated carcinomas carried a risk for LNM compared to Grade 1 and Grade 2 carcinomas; however, in the aforementioned study, univariate analysis was used instead of multivariate analysis. Although in the current study, the most frequent histological grade was Grade $2(n=29 ; 82.9 \%)$, this was not a statistically significant finding. In previous studies, it has been found that perineural invasion was a prognostic factor that mainly affects the length of life ${ }^{(17)}$. As the follow-up of the patients in the current study is still continuing, an evaluation of the prognostic factors and survival could not be conducted.

Nascimbeni et al. ${ }^{(15)}$ have demonstrated that especially in T1 tumors involving the distal third of the rectum, tumor localization affects LNM. Although in the current study it was found that the tumors localized in the middle third of the rectum $(n=7 ; 20 \%)$ and cecum $(\mathrm{n}=7 ; 20 \%)$ affected LNM this was not a statistically significant finding. In the previous studies, the tumor size in T1 colorectal cancers was categorized as tumors of $\leq 2 \mathrm{~cm}$, and $>2 \mathrm{~cm}$. Its effect on LNM has been investigated; however, a statistically significant difference was not found ${ }^{(18-20)}$. In the current study, we evaluated $\mathrm{T} 1, \mathrm{~T} 2, \mathrm{~T} 3$, and $\mathrm{T} 4$, and accepted $4 \mathrm{~cm}$ as the cut- off value for tumor size; however, no statistically significant difference was observed in the current study.

When the literature was examined to evaluate the factors affecting LNM, in some studies the depth of the submucosal invasion $\left(\mathrm{cm}^{3}\right)$ has been reported as a factor that increases the risk of $\operatorname{LNM}^{(15,21)}$. However, in the study of Kitajima et al., ${ }^{(22)}$ as muscularis propria could not be visualized precisely in endoscopic resections, the depth of submucosal invasion was not found to be useful to affect LNM. It has been demonstrated in many studies that malignant polyps cause LNM when present together with other negative factors (Grade 3 or positive surgical margin) ${ }^{(23)}$. The presence of peritumoral lymphocytic response in T1 colorectal cancers is controversial. Some studies mention that the presence of lymphocytic response increases the risk of LNM; others report that the absence of lymphocytic response increases the risk of LNM $^{(24,25)}$. It is known that budding or microtubular structure detected nore frequently than $20 \%$ in pathological examinations increases the risk of LNM in T1 colorectal cancers ${ }^{(24)}$. The mucinous and poorly differentiated tumors have a worse prognosis than well and intermediately differentiated tumors ${ }^{(26)}$. In the study of Ozdemir et al., ${ }^{(27)}$ mucinous tumors were more frequently reported in colorectal cancers that were seen in young patients.

Considering the historical development of the studies investigating the factors that affect LNM in T1 adenocarcinomas of colon tumors, in 1991, Nivatvongs et al. (28) demonstrated that Haggit (14) level 4 invasion was a risk factor; in 1995, Tanaka et al. ${ }^{(12)}$ demonstrated that submucosal invasion $>400$ um, lymphovascular invasion, Type $2 \mathrm{c}$, and Type $2 a+2 c$ poorly differentiated tumors according to 
KUDO classification were risk factors; in 2002, Nascimbeni et al. ${ }^{(13)}$ demonstrated that lymphovascular invasion, SM3 submucosal invasion, involvement of the lower third of the rectum were risk factors. In 2003, Suziki et al. ${ }^{(29)}$ demonstrated that histological grade and submucosal invasion were risk factors, while in 2003, Sakuragi et al. ${ }^{(30)}$ demonstrated that lymphovascular invasion and submucosal invasion were risk factors; and in 2005, Wang et al. (24) demonstrated that histological grade, lymphovascular invasion, inflammation around the tumor, and invasive budding in front of the tumor were risk factors.

In conclusion, the risk of LNM in colorectal cancers is significantly increased in patients with lymphovascular and perineural invasion. Together with more comprehensive studies that will be performed with developing technology and a greater breadth of knowledge, other risk factors affecting LNM will also be found. In this way, it would be helpful to plan adjuvant-neoadjuvant therapy and minimally invasive surgical procedures in colorectal cancers.

\section{REFERENCES}

1. Aktekin A, Güneş P, Müftioğlu T, ve ark. Kolon Kanserlerinde Lenf Nodu Metastazını Etkileyen Faktörler. Kolon Rektum Hastalıkları Dergisi 2009;19(4):172-77.

2. Schmoll HJ, Van Cutsem E, Stein A, et al. ESMO Consensus Guidelines for management of patients with colon and rectal cancer. A personalized approach to clinical decision making. Ann Oncol 2012;23:2479-516. http://dx.doi.org/10.1093/annonc/mds236

3. IwayamaY, Tsuruma T, Mizuguchi T, et al. Prognostic value of HLA class I expression in patients with colorectal cancer. World Journal of Surgical Oncology 2015;13:36. http://dx.doi.org/10.1186/s12957-015-0456-2

4. Sigurdson ER. Lymph node dissection: Is it diagnostic or therapeutic? J Clin Oncol 2003;21:965-67. http://dx.doi.org/10.1200/JCO.2003.11.944

5. Glimelius B, Dahl O, Cedermark B, et al. Nordic Gastrointestinal Tumour Adjuvant Therapy Group. Adjuvant chemotherapy in colorectal cancer: A joint analysis of randomised trials by the nordic gastrointestinal tumour adjuvant therapy group. Acta Oncol 2005;44:904-12.

6. Özdemir Y, Özdemir S, Filiz Aİ, Sücüllü İ, Kurt Y, Yıldız M. Koleraktal kanserlerde lenf nodu oranının prognostik önemi. Balkan Med J 2011;28:86-90.

7. Andre T, Boni C, Mounedji-Boudiaf L, et al. Oxaliplatin, fluorouracil, and leucoverin as adjuvant treatment for colon cancer. N Engl J Med 2004;350:2343-51. http://dx.doi.org/10.1056/NEJMoa032709
8. Adjuvant therapy for patients with colon and rectum cancer. Consens Statement 1990;16-18;8:1-25.

9. Joseph NE, Sigurdson ER, Hanlon AL, et al. Accuracy of determining nodal negativity in colorectal cancer on the basis of the number of nodes retrieved on resection. Ann Surg Oncol 2003;10:213-8. http://dx.doi.org/10.1245/ASO.2003.03.059

10. Compton CC, Fielding LP, Burgart LJ, et al. Prognostic factors in colorectal cancer. College of American Pathologists Consensus Statement 1999. Arch Pathol Lab Med 2000;124:979-94.

11. Nelson H, Petrelli N, Carlin A, et al. Guidelines 2000 for colon and rectal cancer surgery. J Natl Cancer Inst 2001;93:583-96 http://dx.doi.org/10.1093/jnci/93.8.583

12. Tanaka S, Haruma K, Teixeria CR, et al. Endoscopic treatment of submucosal invasive colorectal carcinoma with special reference to risk factors for lymph node metastasis. $J$ Gastroenterol 1995;30:710-17. http://dx.doi.org/10.1007/BF02349636

13. Nascimbeni R, Burgart LJ, Nivatvongs S, Larson DR. Risk of lymph node metastasis in T1 carcinoma of the colon and rectum. Dis Colon Rectum 2002;45:200-06. http://dx.doi.org/10.1007/s10350-004-6147-7

14. Haggitt RC, Glotzbach RE, Soffer EE, Wruble LD. Prognostic factors in colorectal carcinoma arising in adenomas: implications for lesions removed by endoscopic polypectomy. Gastroenterology 1985;89:328-36.

15. Yamamoto $\mathrm{S}$, Watanabe $\mathrm{M}$, Hasegawa $\mathrm{H}$, et al. The risk of lymph node metastasis in T1 colorectal carcinoma. Hepatogastroenterology 2004;51:998-1000.

16. Le Voyer TE, Sigurdson ER, Hanlon A, et al. Colon cancer survival is associated with increasing number of lymph nodes analyzed: A secondary survey of intergroup trial INT-0089. Journal of Clinical Oncology 2003:21; 2912-19. http://dx.doi.org/10.1200/JCO.2003.05.062

17. Shirouzu K, Isomoto H, Kakegawa T. Prognostic evaluation of perineurotic invasion in rectal cancer. AM J Surg 1993;165:233-37. http://dx.doi.org/10.1016/S0002-9610(05)80517-3

18. Oh-e H, Tanaka S, Kitadai Y, Shimamoto F, Yoshirara M, Haruma K. Angiogenesis at the site of deepest penetration predicts lymph node metastasis of submucosal colorectal cancer. Dis Colon Rectum 2001;44:1129-136.

19. Tominaga K, Nakanishi Y, Nimura S, Yoshimura K, Sakai Y, Shimoda T. Predictive histopathologic factors for lymph node metastasis in patients with nonpedunculated submucosal invasive colorectal carcinoma. Dis Colon Rectum 2005;48:92-100.

20. Yasuda K, Inomata M, Shiromizu A, Shiraishi N, Higashi H, Kitano S. Risk factors for occult lymph node metastasis of colorectal cancer invading the submucosa and indications for endoscopic mucosal resection. Dis Colon Rectum 2007;50:1370-76.

21. Kudo S. Endoscopic mucosal resection of flat and depressed types of early colorectal cancer. Endoscopy 1993;25:455-61. http://dx.doi.org/10.1055/s-2007-1010367

22. Kitajima K, Fojımori T, Fuj1 S, et al. SM depth and LNM in SICC Correlations between lymph node metastasis and depth of submucosal invasion in submucosal invasive colorectal carcinoma:a Japanese collaborative study. J Gastroenterol 2004;39:534-43. http://dx.doi.org/10.1007/s00535-004-1339-4

23. Morson BC, Whiteway JE, Jones EA, Macrae FA, Williams 
CB. Histopathology and prognosis of malignant colorectal polyps treated by endoscopic polypectomy. Gut 1984;25:43744. http://dx.doi.org/10.1136/gut.25.5.437

24. Wang HS, Liang WY, Lin TC, et al. Curative resection of T1 colorectal carcinoma: Risk of lymph node metastasis and long-term prognosis. Dis Colon Rectum 2005;48:1182-92. http://dx.doi.org/10.1007/s10350-004-0935-y

25. Egashira Y, Yoshida T, Hirata I, et al. Analysis of pathological risk factors for lymph node metastasis of submucosal invasive colon cancer. Modern Pathology 2004;17:503-11. http://dx.doi.org/10.1038/modpathol.3800030

26. D'Onofrio GM, Tan EG. Is colorectal carcinoma in the young a more deadly disease. Aust N Z J Surg 1985;55:537-40. http://dx.doi.org/10.1111/j.1445-2197.1985.tb00940.x

27. Özdemir Y, Sücüllü İ, Filiz A, ve ark. Genç hastalarda kolorektal kanserlerin klinik ve patolojik özelliklerinin değerlendirilmesi. Kolon Rektum Hast Derg 2009;19:4:168171.

28. Nivatvongs S, Rojanasakul A, Reiman HM, et al. The risk of lymph node metastasis in colorectal polyps with invasive adenocarcinoma. Dis Colon Rectum 1991;34:323-8. http://dx.doi.org/10.1007/BF02050592

29. Suzuki T, Sadahiro S, Mukoyama S, et al. Risk of lymph node and distant metastases in patients with early invasive colorectal cancer classified as Haggitt's level 4 invasion: image analysis of submucosal layer invasion. Dis Colon Rectum 2003;46:203-8.

30. Sakuragi M, Togashi K, Konishi F, Kawamura Y, Okada M, Nagai H. Predictive factors for lymph node metastasis in T1 stage colorectal carcinomas. Dis Colon Rectum 2003;46:162632 .

http://dx.doi.org/10.1007/BF02660767 